\title{
Research on the Relationship Between Social Capital and Social Entrepreneurship Intention: The Mediating Role of Entrepreneurial Bricolage
}

\author{
Ruijun Chen Yingqi Liu* Fei Zhou
}

\author{
School of Economics and Management, Beijing Jiaotong University, Beijing 100044, China \\ *Corresponding author. Email: liuyq@bjtu.edu.cn
}

\begin{abstract}
As a new form of entrepreneurship, social entrepreneurship aims at solving social problems, takes the establishment of social enterprises or non-profit organizations as the main form, and has attracted wide attention and discussion among practitioners, policy makers and scholars. By constructing a theoretical model of social capital and social entrepreneurial intention, this study explores the relationship between social capital and social entrepreneurial intention of Chinese social entrepreneurs or entrepreneurs who are willing to engage in social entrepreneurship. The results showed that social capital has a positive influence on entrepreneurial bricolage and social entrepreneurial intention, entrepreneurial bricolage has a positive influence on social entrepreneurial intention, and entrepreneurial bricolage plays a part of intermediary role between social capital and social entrepreneurial intention. This research will be helpful for social entrepreneurs to recognize their own social capital, effectively obtain resources through social capital and make up the value of resources through entrepreneurship, thus it can stimulate the social entrepreneurial intentions of social entrepreneurs.
\end{abstract}

Keywords: social capital, entrepreneurial bricolage, social entrepreneurial intentions

\section{INTRODUCTION}

As a new form of entrepreneurship, social entrepreneurship aims at solving social problems, takes the establishment of social enterprises or non-profit organizations as the main form. Social entrepreneurship focuses on the creation of social value, supplemented by creation of economic value [1]. Social entrepreneurship has also grown rapidly in the fields of education, health care and environment, and has attracted wide attention and discussion among practitioners, policy makers and scholars [2]. How to encourage more and more people to participate in social entrepreneurship, how to integrate social capital to achieve social entrepreneurship, and then effectively solve more social problems such as the gap between rich and poor in the context of transforming society, uneven medical resources and environmental degradation, insufficient employment and jobs, etc. More social issues have become an important research issue.

As the subjective attitude of entrepreneurs towards entrepreneurship, entrepreneurial intention reflects the individual entrepreneurs' intentions and preference for entrepreneurship, and it is also a prerequisite for the start of social entrepreneurship [3]. The emergence of social entrepreneurial intention is often closely related to the resources of social entrepreneurs. Social capital is a collection of all resources that are related to the network structure both inside and outside enterprises. Social capital possessed by social entrepreneurs can help social entrepreneurs to explore and utilize resources on the basis of providing network relationships, and entrepreneurial bricolage can put together limited resources and highly exploit the value of these resources, thus forming a lasting competitive advantage and enhancing entrepreneurs' selfconfidence in entrepreneurship. However, entrepreneurs with social capital do not necessarily actively acquire resources and start-up entrepreneurship. Therefore, it is important to explore the relationship between social capital and social entrepreneurial intentions from the perspective of social capital, and to verify whether the entrepreneurial bricolage is conducive to the promotion of social entrepreneurial intentions or not.

To reach the goal of the research, this study used SPSS and LISERL8.7 software to test the sample data, explored the relationship between social capital, entrepreneurial bricolage and social entrepreneurial intention. On the basis of the conclusions and contributions of this study, we would put forward corresponding countermeasures on governmental, personal and resource integration perspective. 


\section{LITERATURE REVIEW AND RESEARCH HYPOTHESES}

\subsection{Literature Review}

As a kind of entrepreneurial intention, social entrepreneurial intention refers to the belief and preparation of self-commitment of entrepreneurs who intend to create a social enterprise [4]. At present, the research on the relationship between social capital and entrepreneurial intention mainly focuses on the field of business entrepreneurship. Social capital plays an important role in the emergence of entrepreneurial intention, the creation of new ventures, and the operation of enterprises. Sequeira et al. (2007) [5] explored the relationship between social network and entrepreneurial intention. They found that individual entrepreneurial intention was influenced by individual network relationship, and ultimately promoted entrepreneurs' entrepreneurial behaviour. Through the case study of new social enterprises, Sharir \& Lerner (2006) [6] found that social network, capital accumulation, and public recognition of social ventures were the key elements of social capital for entrepreneurs. They pointed out that these elements help to enhance entrepreneurs' entrepreneurial intentions. Therefore, social capital is an important factor in predicting entrepreneurship. The more capital entrepreneurs have, the more likely they are to embark on the road of entrepreneurship.

In the practice of entrepreneurship, the scarcity of resources restricts the development of enterprises and reduces entrepreneurs' enthusiasm for entrepreneurship. Traditional strategic management and resource-based theory can hardly explain entrepreneurship behavior under high resource constraints. But the theory of entrepreneurial bricolage just breaks through the resource constraints. Based on the in-depth study of 29 entrepreneurs, Baker \& Nelson (2005) [7] found that entrepreneurial bricolage was an effective way for entrepreneurs to survive and grow by utilizing the resources at hand to meet new opportunities or challenge under resource constraints.

\subsection{Research Hypotheses}

\subsubsection{Social Capital and Social Entrepreneurial Intentions}

Social capital theory points out that the accumulation of social capital of entrepreneurs was an important source of entrepreneurs' access to resources. Social capital is often embedded in the individual's social network structure, which is the basis for social entrepreneurship activities. Social capital drove entrepreneurs to implement social entrepreneurship activities. The higher the structural capital, the closer and more frequent the relationship between entrepreneurs and other network subjects.
Therefore, it is helpful for entrepreneurs to obtain more entrepreneurial resources and enhance their selfconfidence, so as to make entrepreneurial intentions stronger [5]. Social entrepreneurs aiming at solving social problems often have good trust and reciprocal relationship with the government and other social organizations. The existence of relationship capital is conducive to strengthening cooperation between the two sides, obtaining more funds and policy support, and reducing venture risk. Therefore, relational capital was conducive to enhance entrepreneurs' social entrepreneurial intention. Cognitive capital, based on common language and values, can make members resonate with each other. Common norms among members can support entrepreneurs' behavior, and resources can be used together to promote entrepreneurs' entrepreneurial intention. Therefore, the following hypothesis are presented:

H1: Social capital is conducive to enhance social entrepreneurial intentions.

H1a: Structural capital is conducive to enhance social entrepreneurial intentions.

H1b: Relational Capital is conducive to enhance social entrepreneurial intentions.

H1c: Cognitive capital is conducive to enhance social entrepreneurial intentions.

\subsubsection{Social Capital and Entrepreneurial Bricolage}

Entrepreneurial bricolage can achieve the creative reorganization of the resources at hand, and guide entrepreneurs to redefine the value of existing resources. Structural social capital provides social entrepreneurs with abundant information and resources. At the same time, it can help entrepreneurs identify effective entrepreneurial opportunities. Through structural social capital, entrepreneurs can obtain rich and diverse information and increase access to resources. By communicating with network members, entrepreneurs can get more effective information. Trust-based relational social capital is conducive to enhance the cooperative relationship among network members, realizing the flow of resources and improving the utilization of resources. When exploiting entrepreneurial opportunities, entrepreneurs tend to take a responsible attitude to achieve a relatively considerable and sustainable profitability effect. Therefore, it can motivate entrepreneurs to bricolage together the resources to maximize profits. In addition, the higher the cognitive social capital, the better the integration of heterogeneous resources, knowledge, and the better the identification of profitable entrepreneurial opportunities. In turn, profitable opportunities will have a positive effect on entrepreneurs. Entrepreneurs can make use of these heterogeneous resources and their own entrepreneurial knowledge to bricolage together the resources they acquire. Therefore, the following hypothesis is presented:

$\mathrm{H} 2$ : Social capital has a positive impact on entrepreneurial bricolage. 


\subsubsection{The Mediating Role of Entrepreneurial Bricolage}

It does not mean that entrepreneurs who can effectively identify their own social entrepreneurship resources will inevitably generate entrepreneurial intention faster. The key is how to maximize the value of their own entrepreneurship resources so as to promote social entrepreneurial intention. social entrepreneurship is not only the production of new products or services, but also the result of a novel and unique thinking mode. As the main component of entrepreneurship activities, entrepreneurial bricolage helps to break the conventions and find new ways to solve problems. entrepreneurial bricolage can break the restriction of resources in the process of entrepreneurship, and achieve the purpose of solving the original insurmountable problems. Entrepreneurial bricolage helps entrepreneurs to put together more valuable resources through social capital, which is more conducive to promoting entrepreneurs to engage in entrepreneurship activities. At the same time, entrepreneurial helps entrepreneurs to better grasp the opportunities in entrepreneurship. It can combine resources with market opportunities more effectively and help entrepreneurs quickly bricolage together the resources they need in the changing market. To sum up, entrepreneurial bricolage helps entrepreneurs maximize the value of resources acquired through social capital, seize business opportunities, and promote entrepreneurs to engage in business activities faster. Therefore, the following hypothesis is presented:

H3: Entrepreneurial bricolage plays an intermediary role between social capital and social entrepreneurial intention.

\section{METHOD}

\subsection{Data Collection and Sample}

The purpose of this study was to investigate the impact of social capital on social entrepreneurial intention and the role of entrepreneurial bricolage in the relationship between social capital and social entrepreneurial intention. Therefore, the sample selection objectives of this study were mainly from social entrepreneurs or entrepreneurs who are willing to engage in social enterprise industry. In this study, 500 questionnaires were distributed, 433 were recovered, 332 were valid, and the valid rate of the questionnaires was $66.4 \%$.

\subsection{Measurement}

In order to test the hypothesis established in this research, the questionnaire design of this study firstly adopts the mature scale which has been validated at China and abroad. Secondly, in order to make the scale more suitable for the needs of this study, the author revised the scale effectively on the basis of the existing scale. The questionnaire was measured by the 7-point Likert scale. For social capital, this study used Klyver and Schtt (2011) [8] for reference and includes 10 measurement items. For entrepreneurial bricolage, based on the measurement scale developed by Senyard et al. (2010) [9], 10 measurement items were designed. For social entrepreneurial intention, this study used Lin and Chen (2009) [10] for reference and includes 10 measurement items.

\section{RESULTS}

In order to ensure the scientificity and validity of regression analysis, this study examined three major problems of regression model: multiple collinearity, sequence correlation and heteroscedasticity. The VIF values of the regression models used in this study all fall within a reasonable region, and there is no problem of multiple collinearities. Sequence correlation only exists when the data is dynamic. Because cross-sectional data are used in this study, and the DW values of each model are close to two, the residual of explanatory variables and independent variables are independent, there is no problem of autocorrelation. Regarding the test of heteroscedasticity, this study combines the least squares method to calculate the correlation between the absolute value of the regression model residual and the independent variable, and finds that the problem of heteroscedasticity does not exist.

Table 1 shows that model 1 takes social capital as independent variable and entrepreneurial bricolage as dependent variable. The regression results show that social capital has a significant positive impact on entrepreneurial bricolage $(\beta=0.518, P<0.001)$. It shows that social capital is beneficial for entrepreneurs to implement entrepreneurial bricolage; therefore, $\mathrm{H} 2$ was accepted.. Model 3 takes social capital as independent variable and social entrepreneurial intention as dependent variable. The results show that social capital and social entrepreneurial intention are positively significant $(\beta=0.575, \mathrm{P}<0.001)$; therefore, $\mathrm{H} 1$ was accepted. At the same time, it can be seen from Table 2 that there is a significant relationship between structural capital and social entrepreneurial intention $(\beta=0.490, \mathrm{P}<0.001 ; \beta=0.425, \mathrm{P}<0.001)$; therefore, H1a was accepted. The relationship between relational capital and social entrepreneurial intention is significant $(\beta=0.203, \mathrm{P}<0.001 ; \beta=0.136, \mathrm{P}<0.01)$; therefore, H1b was accepted. Cognitive capital has significant effect on all dimensions of social entrepreneurial intention $(\beta=0.149, \mathrm{P}<0.01 ; \beta=0.169, \mathrm{P}$ $<0.01)$; therefore, H1c was accepted. 
This study used stratified regression method to test the intermediary effect. After adding intermediary variable in model 4, the direct effect of social capital on social entrepreneurial intention shows a significant positive correlation $(\beta=0.575, \mathrm{P}<0.001)$, and social capital has a significant positive correlation with entrepreneurship bricolage $(\beta=0.518, P<0.001)$. Finally, social capital and entrepreneurship bricolage are taken as independent variables to test their social creation. The results show that the effect of social capital on social entrepreneurial intention is positively correlated $(\beta=0.364, \mathrm{P}<0.001)$. The effect of entrepreneurial bricolage on social entrepreneurial intention is also significant $(\beta=0.408, \mathrm{P}<$ $0.001)$. The adjusted $R^{2}$ value is significantly increased, indicating that entrepreneurial bricolage has an important explanatory role in social entrepreneurial intention, indicating that entrepreneurial bricolage has an important role in social capital and social entrepreneurial intention; therefore, H3 was accepted.

Table 1 Regression analysis results

\begin{tabular}{|l|l|l|l|l|}
\hline \multirow{2}{*}{ Variable } & $\begin{array}{l}\text { Entrepreneurial } \\
\text { bricolage }\end{array}$ & Social entrepreneurial intention. & $\begin{array}{l}\text { Social } \\
\text { intention. }\end{array}$ \\
\cline { 2 - 5 } & Model1 & Model 2 & Model 3 & Model 4 \\
\hline Gender & -0.042 & -0.008 & -0.016 & 0.001 \\
\hline Age & 0.022 & -0.024 & -0.019 & -0.028 \\
\hline Education level & $0.093^{*}$ & -0.015 & 0.044 & 0.006 \\
\hline Industry & -0.007 & -0.005 & -0.004 & -0.001 \\
\hline Social capital & $0.518^{* * *}$ & & $0.575^{* * *}$ & $0.364^{* * *}$ \\
\hline Entrepreneurial bricolage & & $0.598^{* * *}$ & $0.408^{* * *}$ \\
\hline$R^{2}$ & 0.283 & 0.356 & 0.333 & 0.452 \\
\hline Adjusted $R^{2}$ & 0.272 & 0.346 & 0.322 & 0.442 \\
\hline F & $25.702 * * *$ & $32.510^{* * *}$ & $44.691 * * *$ \\
\hline Note: The constant term is omitted from the model; $* \mathrm{p}<0.05, * * \mathrm{p}<0.01, * * * \mathrm{p}<0.001$ & & \\
\hline
\end{tabular}

Table 2 Regression analysis of social capital dimensions on social entrepreneurial intention

\begin{tabular}{|l|l|l|l|}
\hline & Dependent Variable \\
\hline Variable & Entrepreneurship aspiration & $\begin{array}{l}\text { Feasibility } \\
\text { entrepreneurship }\end{array}$ & of \\
\hline Gender & -0.016 & -0.047 & -0.022 \\
\hline Age & -0.005 & -0.031 & -0.016 \\
\hline Education level & 0.082 & 0.016 & 0.046 \\
\hline Industry & 0.004 & -0.004 & -0.005 \\
\hline Structural capital & $0.490^{* * *}$ & $0.425^{* * *}$ & $0.483^{* * *}$ \\
\hline Relational capital & $0.203^{* * *}$ & $0.136^{* *}$ & $0.180^{* * *}$ \\
\hline Cognitive capital & $0.149^{* *}$ & $0.169^{* *}$ & $0.169^{* * *}$ \\
\hline$R^{2}$ & 0.355 & 0.279 & 0.349 \\
\hline Adjusted $R^{2}$ & 0.341 & 0.264 & 0.335 \\
\hline F & $25.458^{* * *}$ & $17.928^{* * *}$ & $24.830^{* * *}$ \\
\hline Note: The constant term is omitted from the model;*p<0.05, **p<0.01, ***p<0.001 \\
\hline
\end{tabular}

\section{CONCLUSIONS}

This study started with the analysis of the content of social capital, introduces the method, means of resource bricolage, and then analyse the process of social capital influencing social entrepreneurial intention, finally obtain some meaningful conclusions and enlightenments.

Firstly, all dimensions of social capital have a positive impact on social entrepreneurial intention. As an important capital, relationship capital is indispensable to any entrepreneur. As the essence of relationship capital, trust and intimacy are the cornerstones of maintaining longterm relationship between people. Structural capital reflects the scale and stability of social relations owned by entrepreneurs, and determines the degree of difficulty for entrepreneurs to obtain resources. Cognitive capital reflects the content shared by individuals and groups, involving common language, standpoints and attitudes. This also further enlightens us that if entrepreneurs want to succeed in entrepreneurship, they need to integrate the cognitive level and the mainstream values, so that they can get the support of the public and reduce the resistance in social entrepreneurship.

Secondly, entrepreneurial bricolage plays a part of intermediary role between social capital and social entrepreneurial intention. The promotion of social entrepreneurial intention is a resource integration process 
entrepreneurs. Journal of World Business, 41(1)

(2006)6-20. DOI:

https://doi.org/10.1016/j.jwb.2005.09.004

[7] Baker, T., \& Nelson, R. E. Creating something from nothing: Resource construction through entrepreneurial bricolage. Administrative science quarterly, 50(3) (2005)329-366. DOI: https://doi.org/10.2189/asqu.2005.50.3.329

[8] Klyver, K., \& Schøtt, T. How social network structure shapes entrepreneurial intentions. Journal of Global Entrepreneurship Research, 1(1) (2011)3-19.

[9] Senyard, J. M., Davidsson, P., \& Steffens, P. R. Venture creation and resource processes: using Bricolage sustainability ventures. Proceedings of the 7th AGSE International Entrepreneurship Research Exchange, (2010) pp:637-648.

[10] Liñán, F., \& Chen, Y. W. Development and crosscultural application of a specific instrument to measure entrepreneurial intentions. Entrepreneurship theory and practice, 33(3) (2009)593-617. DOI:

https://doi.org/10.1111/j.1540-6520.2009.00318.x

[1] Saebi, T., Foss, N. J., \& Linder, S. Social
entrepreneurship research: Past achievements and future promises. Journal of Management, 45(1) (2019)70-95. DOI: https://doi.org/10.1177/0149206318793196

[2] Phillips, W., Lee, H., Ghobadian, A., O’Regan, N., \& James, P. Social innovation and social entrepreneurship: A systematic review. Group \& Organization Management, 40(3) (2015) 428-461. DOI: https://doi.org/10.1177/1059601114560063

[3] Ji Wang, Qian Li. The influence mechanism of entrepreneurial traits on green entrepreneurial Willingness: An Empirical Study Based on the sample of college students. Research on financial issues, (06) (2017)134-139. DOI:

[4] Ip, C. Y., Wu, S. C., Liu, H. C., \& Liang, C. Revisiting the antecedents of social entrepreneurial intentions in Hong Kong. International Journal of Educational Psychology, 6(3) (2017) 301-323. DOI: http://dx.doi.org/10.17583/ijep.2017.2835

[5] Sequeira, J., Mueller, S. L., \& McGee, J. E. The influence of social ties and self-efficacy in forming entrepreneurial intentions and motivating nascent behavior. Journal of Developmental Entrepreneurship, 12(03) (2007)275-293. DOI: https://doi.org/10.1142/S108494670700068X

[6] Sharir, M., \& Lerner, M. Gauging the success of social ventures initiated by individual social 